\title{
Something Old, Something New?: Re-Theorizing Patriarchal Relations and Privatization from the Outskirts of Family Law
}

Shelley A. M. Gavigan

Osgoode Hall Law School of York University, sgavigan@osgoode.yorku.ca

Source Publication:

Theoretical Inquiries in Law. Volume 13, Issue 1 (2012), p. 271-302.

Follow this and additional works at: https://digitalcommons.osgoode.yorku.ca/scholarly_works (c) (1) $(9)$

This work is licensed under a Creative Commons Attribution-Noncommercial-No Derivative Works 4.0 License.

\section{Recommended Citation}

Gavigan, Shelley A. M. "Something Old, Something New?: Re-Theorizing Patriarchal Relations and Privatization from the Outskirts of Family Law." Theoretical Inquiries in Law 13.1 (2012): 271-302.

This Article is brought to you for free and open access by the Faculty Scholarship at Osgoode Digital Commons. It has been accepted for inclusion in Articles \& Book Chapters by an authorized administrator of Osgoode Digital Commons. 


\title{
Something Old, Something New? Re-Theorizing Patriarchal Relations and Privatization from the Outskirts of Family Law
}

\begin{abstract}
Shelley A.M. Gavigan*
Canada has an enviable record of relatively progressive and egalitarian legislation and policy in relation to Canadian family forms. The country's constitutional guarantees of equality and multiculturalism provide the legal foundation for this record. In particular, Canada's leadership in the recognition of and support for same-sex relationships in family law and social policy is widely acknowledged.

This is, however, also deeply contested terrain: Feminist legal scholars informed by critical political economy argue that recent family law advances in Canada sit compatibly with neo-liberal social policy and restructuring of the welfare state; the neo-conservative and religious right assert that the fundamental nature of family
\end{abstract}

* Professor and Associate Dean, Osgoode Hall Law School, York University, Toronto, Ontario, Canada. sgavigan@osgoode.york.ca. An earlier version of this Article was prepared for the Rights and Obligations of the Contemporary Family: Theorizing Individualism, Families and the State Conference, co-sponsored by Cegla, Buchmann Faculty of Law, Tel Aviv University and Cornell Law School (December 15-17, 2010). I was honored by the invitation of Dr. Dafna Hacker and Professor Cynthia Grant-Bowman to participate in the Conference, and I thank them for their extraordinary support in this process. I thank Dr. Yuval Merin for his insightful commentary on the conference paper and my fellow conference participants for their comments and for the richness of the discussion throughout the conference. I also acknowledge with great thanks the research assistance of Anastasia Mandziuk (Osgoode JD 2012) and Joy Mathews (Osgoode JD 2011), the technical assistance of Miriam Spevack, the comments of Karen E. Andrews on earlier drafts of this Article, and the sharp eyes and good advice of the journal editors. The errors or weaknesses that remain are, of course, mine alone. 
has been undermined by the recognition of same-sex marriage, facilitating the legal recognition of polygamous relationships, among others. Still others take the view that despite a liberal, progressive and formally egalitarian approach to family, the legal recognition of same-sex marriage in Canada reflects and reinforces a historically patriarchal, heterosexual institution that should be jettisoned rather than embraced. These arguments raise issues and illustrate more generally the tensions in state and legal construction and regulation of familial relations - historically and in the current context. In this Article, I re-theorize the significance of patriarchy and the relationship between patriarchal relations and the discourse of privatization in critical family law. Using the experience of women from the "outskirts" - lesbian spouses, welfare mothers, and women in polygamous relationships - I demonstrate the limits of any theory of "privatization" that does not theorize patriarchal relations. In particular, I identify and analyze the impediments to equality posed by increasingly invisible, but no less enduring, patriarchal familial ideologies in order to envision forms of family law reform and state social policy that might actually improve gendered and generational familial relations and transform the social landscape more generally.

\section{INTRODUCTION}

"Are the suburbs there to keep us in or to keep them out?"I

Is family law there to keep them in or to keep us out?

It was once tantamount to a feminist axiom to refer to the pride of place occupied in state and social policy by the patriarchal nuclear family, and to the celebration of its importance to social stability, the values of its domesticity, and the roles of male breadwinners and dependent housewives. ${ }^{2}$ However,

1 Bernadette Basinger (Terrance Stamp) poses this rhetorical question to her two friends, fellow drag performers, on their road trip from Sydney to Alice Springs in Australia's Northern Territories, in Stephen Elliott's film, The Adventures of Priscilla, Queen of the Desert (Gramercy Pictures, 1994).

2 See, e.g., Shelley A.M. Gavigan \& Dorothy E. Chunn, From Mother's Allowance to Mothers Need Not Apply: Canadian Welfare Law as Liberal and Neo-Liberal Reform, 45 OsGoode HaLL L.J. 733 (2007) [hereinafter Gavigan \& Chunn, From Mother's Allowance]; Shelley A.M. Gavigan \& Dorothy E. Chunn, Women, the State, and Welfare Law: The Canadian Experience, in THE LEGAL TENDER OF 
as many scholars also have noted, the precise form of the legal supports for the patriarchal family has been more uneven than constant. There have been important shifts away from "pure" unmediated patriarchy. ${ }^{3}$ Indeed, it has been argued that in the transition to and consolidation of capitalist social relations, the legal underpinnings of patriarchy were eroded. ${ }^{4} \mathrm{~A}$ less sweeping claim can surely be made: that family law reform together with other areas of law reform (such as decriminalization of abortion and the repeal of the marital rape exemption, two examples from criminal law) have also been sites of struggle, and of inhibition and mediation of patriarchal relations. Recently in the Canadian context, even marriage - historically one of the most important sites for the reproduction of relations of domination, subordination and subservience - has been reinvented on new ideological terms and has emerged as the pristine site of formal equality.

The relationship between law - as opposed to state and social policy - and patriarchy is arguably an uneven one, and this unevenness has led both critics and defenders of patriarchy to suggest its demise. However, to borrow from Mark Twain, reports of the death of patriarchy have been greatly exaggerated.

This Article explores ongoing tensions and contradictions in the area of family law through feminist socio-legal theorizing at the outskirts of "law's families." It argues that despite their apparently disparate locations and uneven relationships to conventional family law, the poor single mother on welfare, the lesbian spouse, and the second and subsequent wives of polygamy can illuminate and deepen an understanding of the central premises of family law, and thereby assist in the ongoing project of its theorization and re-theorization.

Gender: Law, Welfare and the Regulation of Women's Poverty 47 (Shelley A.M. Gavigan \& Dorothy E. Chunn eds., 2010); see also Elizabeth Wilson, Women and the Welfare State (1983); Women, the State and Welfare (Linda Gordon ed., 1990); Patricia Allatt, Stereotyping: Familism in the Law, in LAw, State AND SocieTy 177 (Bob Fryer et al. eds., 1981); Mary McIntosh, The State and the Oppression of Women, in Feminism AND MATERIAlism: WoMEN AND Modes of Production 254 (Ann Marie Wolpe \& Annette Kuhn eds., 1978).

3 See, e.g., Dawn H. Currie \& Marlee Kline, Challenging Privilege: Women, Knowledge and Feminist Struggles, 2 J. Hum. Just. 1 (1991); Shelley A.M. Gavigan, Petit Treason in Eighteenth-Century England: Women's Inequality Before the Law, 3 CAN. J. WOMEN \& L. 335 (1989-1990); Juliet Mitchell, Women and Equality, in THE Rights AND Wrongs OF WOMEN 379 (Juliet Mitchell \& Ann Oakley eds., 1976); Carol Smart \& Julian Brophy, Locating Law: A Discussion of the Place of Law in Feminist Politics, in WOMEN IN LAW: EXPLORATIONS IN Law, Family and Sexuality 1 (Julian Brophy \& Carol Smart eds., 1985). WILSON, supra note 2 , at 42 . 
The claims for right of access by some, and resistance to relegation by others, to law's family tent have occupied important, yet contested, social, political and theoretical spaces for the last two decades. A new discourse invoking equal spouses and equal families, accompanied by critiques of heterosexual privilege, hetero-normativity, privatization, assimilation, and conjugality, has dotted the critical feminist and queer legal intellectual landscape. The implications of shifting and expanding definitions of familial and spousal relations have been subjected to critical analyses by feminist scholars employing, inter alia, discourses of "privatization" and "familialization."

Still more recently, the debates about the implications of the criminalization of polygamy, and its provenance in an era of prescribed, and legislatively enforced, conventional Christian monogamy, ${ }^{5}$ have found a place at the table in the family law tent. Constitutional law scholars, as well as courtappointed amicus curiae who characterize polygamy's alleged mischief as "inscrutable," worry about the implications of its status as a crime for vulnerable and marginalized women and children of polygamy, ${ }^{7}$ and argue that its continued criminalization in $\mathrm{Canada},{ }^{8}$ including the sweep of the

5 Historian Sarah Carter has demonstrated that this was an important, if challenging, undertaking for the young Canadian state as it sought to settle and transform the western prairies into an image and practice consonant with white, English-speaking values. Although the First Nations were an important target of legislatively enforced monogamy, other "non-conformist marriages" were also regarded as problems, especially American Mormons, but also Russian Doukhobor and Ukrainian immigrants and aspirant Chinese immigrants. See Sarah Carter, The Importance of Being Monogamous: Marriage and NationBuilding In Western Canada to 1915, at 20 (2008).

6 Susan G. Drummond, Polygamy's Inscrutable Criminal Mischief, 47 Osgoode Hall L.J. 317 (2009).

7 Martha Bailey, Beverley Baines, Bita Amani \& Amy Kaufman, Expanding Recognition of Foreign Polygamous Marriages: Policy Implications for Canada, in Polygamy in Canada: Legal and Social Implications for Women and Children: A Collection of Policy Research Reports 19 (Angela Campbell et al. eds., 2005); Beverley Baines, Polygamy's Challenge: Women, Religion and the Post-Liberal State, 2 Les ATEliERs De L'ÉTHIQUe 23 (2007) (Can.), available at http://www.creum.umontreal.ca/IMG/pdf_Vol.2N1.pdf.

8 Criminal Code, R.S.C. 1985 , c. C-46, s. 293 (Can.) provides in part that a polygamist is:

(2) Everyone who

(a) Practices or enters into or in any manner agrees or consents to practice polygamy or enter into

(i) Any form of polygamy, or 
offense, potentially captures many relationships and violates the Canadian Charter of Rights and Freedoms, ${ }^{9}$ including the right to freedom of religion. ${ }^{10}$

The central argument of this Article is that despite their different foci, feminist rethinkings of polygamy, privatization, conjugality, and familialization share unacknowledged, unbroken common ground represented by a neglect to subject to serious scrutiny the normatively and ideologically patriarchal foundation of apparently "privatized" family forms, whether they be polygamous, same-sex, or poor mother-led. Even in the Canadian context where same-sex marriage has been accepted, where couples need not marry in order to access health and extended care benefits, and where some provinces have extended their family property regimes to include unmarried cohabiting partners, the extent to which discourses, common sense understandings, and social practices relating to families are informed by patriarchal ideology continues to be neglected by legislatures, policymakers, and feminist critics alike. Without an appreciation of the power and enduring appeal of patriarchal ideologies, of their complexities and contradictions, and of the barriers and constraints they impose, the development of alternative perspectives regarding gender and familial relations, and of real gender equality within and without the family, will remain an illusory ideal in Canadian society. This, as I have argued before," requires a particular form of theoretical engagement which

(ii) Any kind of conjugal union with more than one person at the same time, whether or not it is by law recognized as a binding form of marriage.

9 Canadian Charter of Rights and Freedoms (Part I of the Constitution Act, 1982, being Schedule B to the Canada Act, 1982, c.11 (U.K.)).

10 See Drummond, supra note 6; Wendy Stueck, Polygamy on Trial, Globe \& MaIL, Nov. 22, 2010, at A7. Drummond offers a novel interpretation of the scope of this prohibition in support of her argument that its breadth and vagueness violate section 7 of the Canadian Charter of Rights and Freedoms. Focusing on the requirement of "conjugal union" in the section, and offering a novel interpretation thereof, Drummond has come out as a polygamist and has invited criminal prosecution: having been separated but not yet divorced from her husband, she entered into a new relationship and began to live with another man. Drummond believes she found herself on the wrong side of the criminal law. Invoking the language of section 293, she argues that she had entered into a "conjugal union with more than one person at the same time." Leaving aside my own view that she had left one conjugal union and entered into another, there are, as I discuss below, different approaches to the significance of conjugality to cohabitation as between Canadian welfare law and family law.

11 See, e.g., Shelley A.M. Gavigan, Legal Forms, Family Forms and Gender Norms: What Is a Spouse?, 14 CAN. J.L. \& Soc'y 129 (1999); Shelley A.M. Gavigan, Paradise Lost, Paradox Revisited: The Implications of Feminist, Lesbian and Gay Engagement to Law, 31 Osgoode Hall L.J. 589 (1993) [hereinafter Gavigan, 
analyzes the form(s) of law and the content of social relations, often rendered less visible.

The argument is advanced in two major Parts: Part I demonstrates the changing contours of the Canadian legal framework and Canadian family law's response to "new" families, notably same-sex families and introduces the two theoretical axes of the Article: law's relationship to patriarchal relations and law's relation to privatization. In Part II of the Article, I use three exemplars drawn from the outskirts of family law - lesbian spouses, welfare mothers, and polygamous wives - to demonstrate the limits of the discourse of privatization, the enduring relevance of patriarchal familial ideology, and ultimately the uneven and contradictory contribution of law.

\section{Families and Law: The Changing Contours of the Canadian Legal Landscape}

Canada does have an enviable record of relatively progressive legislation and policy in relation to Canadian family forms. Constitutional authority is divided between the federal and provincial levels of government. For instance, marriage and divorce fall within federal jurisdiction. Early in the twenty-first century, the requirement that marriage be restricted to persons of the opposite sex was on shaky legal grounds in Canada. Building on a 1999 decision of the Supreme Court of Canada that struck down the opposite sex requirement in Ontario's legislative definition of "spouse" for the purpose of spousal support as violating the Charter's equality guarantees, ${ }^{12}$ lesbian and gay activists went to court to make the case for the legitimacy and legality of same-sex marriage. And, they enjoyed success.

By the end of a frenzied litany of victories in 2003-2004 in provincial courts across the country upholding the challenges to the federal Marriage Act,${ }^{13}$ beleaguered government lawyers had ceased to oppose the applications

Paradise Lost]; see also Dorothy E. Chunn. \& Shelley A.M. Gavigan, Welfare Law, Welfare Fraud, and the Moral Regulation of the 'Never Deserving'Poor, 13 Soc. \& Legal STud. 219 (2004).

12 M. v. H., [1999] 2 S.C.R. 3 (Can.).

13 See, e.g., Halpern v. Toronto (City), [2003] 172 O.A.C. 276, (Can. Ont. C.A.); EGALE Canada Inc. v. Canada (Att'y Gen.), [2003] 13 B.C.L.R 4th 1 (Can. B.C. C.A.) (additional reasons for the B.C. C.A decision are reported in (2003), 42 R.F.L. 5th 341 (Can. B.C. C.A.)); Hendricks v. Québec (Att'y Gen.), [2004] 238 D.L.R. 4th 577 (Can. Que. C.A.); Vogel v. Canada (Att'y Gen.), [2004] M.J. No. 418, 2004 CarswellMan 527 (Can. Man. Q.B.); W.(N.) v. Canada (Att'y Gen.), [2004] 11 R.F.L. 6th 162 (Can. Sask. Q.B.). 
of same-sex litigants. The federal government drafted and referred a new Civil Marriage bill to the Supreme Court of Canada in 2003 for determination of its constitutionality. In 2004, over the strenuous opposition of interveners representing many conservative religious and advocacy groups, the Supreme Court affirmed the constitutionality of proposed federal legislation that for the first time in Canadian history defined civil marriage "as the lawful union of two persons to the exclusion of all others."14 Same-sex marriage had been won.

Beyond marriage and divorce, numerous federal statutes dealing with matters under federal jurisdiction (such as old age security, pensions, employment insurance, income tax, immigration, Criminal Code, and the Indian Act, to cite only a fraction) also contemplate, define and, inevitably, regulate spousal and familial relations. In response to the 1999 Supreme Court decision, the Canadian government had introduced The Modernization of Benefits and Obligations Act, ${ }^{15}$ which amended the definitions of spouse in sixty-seven federal statutes to bring them into line with the Supreme Court's decision.

The Law Commission of Canada, since dismantled by the federal government, continued to contribute to and develop the public discourse through the release of its report, Beyond Conjugality, which reconsidered the legislative requirement of conjugality and proposed an alternative methodology for analyzing whether relationships are relevant to the distribution of benefits under legislation. The Commission called on the federal government to develop a still "more comprehensive and principled approach to the legal recognition and support of the full range of close personal relationships among adults." ${ }^{\prime 6}$ Beyond Conjugality proposed a new methodology, which would move beyond conventional or unexamined assumptions about the relevance or legal recognition of relationships in favor of a four-step process that would interrogate from first principles, asking (1) whether the legislation pursues a legitimate policy objective; (2) if so, whether relationships matter; (3) if so, whether the policy objectives could be met by permitting individuals to self-define their relevant relationships; and (4) if self-definition is not appropriate, whether the legislation could be revised to capture the relevant range of relationships. ${ }^{17}$

As I will discuss further below, prior to the Law Commission's carefully considered, principled methodological approach to determining whether, why,

14 Re Same-Sex Marriage (2004), 12 R.F.L. 6th 153, 246 D.L.R. 4th 193, 2004 CarswellNat 422 (Can.).

15 Modernization of Benefits and Obligations Act, S.C. 2000, c. 12 (Can.).

16 Law Commission of Canada, Beyond Conjugality: Recognizing and Supporting Close Personal Relationships, at ix (2001).

17 Id. at $30-37$. 
and how relationships matter in legislation, some provincial welfare legislation had already jettisoned "conjugality" or "sexuality" or "cohabitation" as relevant indicia of spousal relationships, for other and sometimes less than principled reasons. In Canada, the provinces have jurisdiction to enact legislation relating to family property, child and spousal support, child custody, succession, child welfare and adoption, and social assistance. As a result, there are ten provincial and two territorial law regimes. Even so, there are more similarities than differences between the provincial regimes.

Looking at Ontario, Canada's most populous province, one can see the importance placed on the family, as well as a formal commitment to equality within marriage, equitable sharing and settlement, partnerships, mutuality, and gender neutrality, expressed by the preamble to its Family Law Act. ${ }^{18}$ Two forms of spousal relationships are contemplated by the Ontario regime: The provisions governing family property and matrimonial home extend only to legally married spouses; but a more expansive definition is found later in that part of the legislation that addresses spousal support. Here, "spouse" includes both the legally married as well as any two persons who either have cohabited continuously for a period of three years, or who have cohabited in a relationship of some permanence, if they are the natural or adoptive parents of a child. ${ }^{19}$ And, although polygamy continues to be a criminal offense in Canada, ${ }^{20}$ the province of Ontario offers family law protection for the purposes of family property and spousal support to a spouse of a marriage "that is actually or potentially polygamous, if [the marriage] was celebrated in a jurisdiction whose system of law regards it as valid."21 "Step-parent" adoption of children by lesbians and gay couples has been permitted since 1995, thanks to a decision of the Ontario Court of Justice. ${ }^{22}$ Importantly as well, the Children's Law Reform Act (CLRA) has abolished the concept of illegitimacy, and while a mother and father have equal rights to custody of a

18 Family Law Act, R.S.O. 1990, c. F.3 (Can.) states that:

Whereas it is desirable to encourage and strengthen the role of the family, and whereas for that purpose it is necessary to recognize the equal position of spouses as individuals within marriage and to recognize marriage as a form of partnership and whereas in support of such recognition it is necessary to provide in law for the orderly and equitable settlement affairs of the spouses upon the breakdown of the partnership, and to provide for other mutual obligations in family relationships, including the equitable sharing by parents of responsibility for their children ....

19 Id. s. 29.

20 Criminal Code, R.S.C. 1985, c. C-46, s. 293 (Can.).

21 Family Law Act, R.S.O. 1990, c. F-3, s. 1(2) (Can.).

22 Re K., [1995] 23 O.R. 3d 679 (Can. Ont. Ct.). 
child, any person may apply for custody of or access to a child. ${ }^{23}$

In a groundbreaking decision in 2007, the Ontario Court of Appeal expanded the content of law's family tent even further when it allowed the appeal of a lesbian "social" parent who had applied for a declaration that she was a mother of a child within the meaning of the CLRA, Part II, section 4, which provides in part that:

(1) Any person having an interest may apply to a court for a declaration that a male person is recognized in law to be the father of a child or that a female person is the mother of a child.

(3) Where the court finds on the balance of probabilities that the relationship of mother and child has been established, the court may make a declaratory order to that effect.

This case involved a lesbian couple, their two year old child and the child's biological father. AA sought to be recognized not only as a parent, but as a mother of the child DD, whom she and CC, her partner and the child's biological mother, were raising. ${ }^{24}$ Prior to the birth of DD, AA and CC had been cohabiting as same-sex partners for eleven years. ${ }^{25}$ They had celebrated their relationship in a secular commitment ceremony in 1992 attended by more than one hundred guests. They had discussed the possibility of having children, but had waited until their careers were more firmly established. By 1999, AA had been called to the Bar and was employed as a lawyer; CC had secured an appointment as a university professor.

Having achieved this measure of security in their professional careers, they turned their minds to having a child and agreed that $\mathrm{CC}$ would be the biological mother. They also agreed that it "would be in their future child's best interests to know his or her biological father and for the father to play an active role in the child's life." ${ }^{26}$ They entered into a discussion with a longtime male friend, BB, a university professor, spouse to another woman, and father of three children. AA, CC, and BB ultimately "made a mutual commitment whereby $\mathrm{AA}$ and $\mathrm{CC}$ would be the primary custodial and decision-making parents, but BB would also have an active and participatory role in the child's

23 Children's Law Reform Act, R.S.O. 1990, c. C-12, s. 21(1) (Can.).

24 A.(A.) v. B.(B.), (2007), 83 O.R. (3d) 561; 35 R.F.L.(6th) 1 (Can. Ont. C.A.).

25 A.(A) v. B.(B.), (2003), 225 D.L.R. (4th) 371; 38 R.F.L. (5th) 1; (Can. Ont. S.C.).

26 [2003] O.J. No. 1215 ๆ3. 
upbringing." ${ }^{27}$ It is not clear whether BB's spouse and children formed part of the consultation process and "mutual commitment."

DD was born on February 6, 2001. AA and CC regarded each other as having equal status and responsibility in relation to the little boy. BB's relationship to and involvement with DD and his lesbian parents was described in the following terms by the trial judge:

$\mathrm{BB}$ visits the child twice a week. On Tuesdays, he has time with the children independently of AA and CC. On Thursdays, he joins them for a family dinner together which sometimes also involves his other children and the woman with whom he cohabits .... BB has not been asked to provide any ongoing or regular financial support but he does support the child informally and indirectly. All of the child's needs are being met. ${ }^{28}$

However, AA wanted to be recognized as the child's mother. It would have been possible for $\mathrm{AA}$ and $\mathrm{CC}$ to make a joint application for $\mathrm{AA}$ to adopt the child, but an adoption order would have resulted in the legal severing of the child's formal legal relationship with one or other of the biological parents. ${ }^{29}$ It would have been open to the lesbian couple to make a joint application as spouses for AA to adopt the child and thus formally and legally define both of them as the child's parents, and thereby retain the parental dyadic unit. This, however, would have required the father's consent. While such an adoption would have been an "open" one, as the father was known and involved, the adoption order would have resulted in the legal severance of the child's relationship to the father, as is the case in all adoptions in Ontario, including "step-parent" adoptions. It appears that he was not prepared to relinquish his legal relationship to the child and, apparently and importantly, the lesbian couple was not prepared to press him on this issue. Rather than create a lesbian family, they felt the child needed a father.

AA's application at first instance was denied; however, she appealed to the Ontario Court of Appeal, where she experienced more success. The Court of Appeal allowed her appeal and made the declaration that she sought. Thus, as a result of the court's declaration under the CLRA, AA was held to be DD's mother in addition to his biological mother, CC. BB's status remained unchanged.

This case is clearly significant not simply for the apparently innovative, apparently progressive legal result. On one reading, it might be observed that

27 Id. $₫ 4$.

28 Id. If 6-7.

29 Child and Family Services Act, R.S.O 1990, c. 11, s. 158(2) (Can.). 
the form of conventional legal parenthood has been transcended, the normative dyad of mother and father de-centered, and a new form of family recognized. However, it can be argued with equal force that the definition of "parent" in many forms of Canadian family law legislation already contemplates a broader range of parent-child relationships beyond biological mother and father. These statutes provide that the definition of a parent of a child includes any person who has demonstrated a settled intention to treat a child as a child of his or her family (other than foster parents who are being remunerated for their care-giving work ${ }^{30}$ ) and that, in addition to a child's parent, "any other person may apply to a court for an order respecting custody of or access to the child or determining any aspect of the incidents of custody of the child."'31

However, I argue for a deeper reading of the implications of this case of the three parents, one that calls for an analysis of both the form and content of the social and legal relations. It is not enough simply to widen the family law tent or challenge the normative dyad either as parents, as mother/father, or spouses. Surely, a closer reading and analysis of the content of the legal recognition yields a still more entrenched ideological formation - that of patriarchy: the importance of the idea of a father (although not necessarily the material support, as in this case). What can be a more fundamental expression of patriarchal ideology than the expressed belief of lesbian parents that their child's best interests require not simply a man, but a father in his life? Thus, although heralded as a victory for the lesbian parents, this case also represented a victory for the man whose importance as father was accepted without question by the lesbians even before the child was conceived, and long before they went to court.

\section{A. The Context and Form of (Family) Law's Mediation of Patriarchal Relations}

This Article revisits and renews my commitment to an approach to family law that has long informed my work, one that maintains that an historicallyinformed analysis of the form and content of law and of social and familial relations is important:

The language of gender neutrality now saturates family law so thoroughly that it is easy to forget how until recently the key figures in the legal relations of (nuclear) family law were understood to be only legally married husbands, wives and their infants. ... Historically, married women, widows, common law wives, deserted wives, and

30 See, e.g., Family Law Act, R.S.O. 1990, c. F.3, s. 1 (Can.).

31 Children's Law Reform Act, R.S.O. 1990, c. C.12, s. 21(1) (Can.). 
single mothers have been dealt with differently at law. The closer one gets to property, the tighter the legal definition of spouse and the heightened significance of legal marriage..$^{32}$

Three premises thus inform my analysis. ${ }^{33}$ First, despite myriad fault lines and cracks, commitment to the idealized model of the nuclear family and, to a certain extent, to its needs, informed the legislation and social policy of the pre-Keynesian welfare state. Second, one of the innovations of both prewar and more notably postwar social policy in Canada was the introduction of a handful of universal social programs that no longer exist in the form in which they were introduced, if at all. ${ }^{34}$ Third, and most importantly, the postwar social policy initiatives in Canada neither supplanted nor replaced the patriarchal nuclear family as the primary site of obligation and responsibility for family members. ${ }^{35}$

The first wave of mother's allowances and social assistance programs was designed to compensate for patriarchal losses or failures rather than to transform or alter the family's shape or place. ${ }^{36}$ As Mary McIntosh observed in an early feminist intervention on the relationship between women and the capitalist state, the early British welfare state understood (or seemed to understand) that the nuclear family could not by itself provide all the services required to reproduce a healthy population, such as education and healthcare, to cite but two examples..$^{37}$ Thus, state support for the nuclear family simultaneously celebrated it, insisted upon its centrality within society, and recognized its limits and frailties, not least that it could not deliver all that was expected of it.

The family and familial relations have been the site and subject of myriad legislative instruments and social practices. The experience of poor families

32 Shelley A.M. Gavigan, Equal Families, Equal Parents, Equal Spouses, Equal Marriage: The Case of the Missing Patriarch, 33 Sup. Cr. L. Rev. 317, 342 (2006) (reprinted in Diminishing Returns: Inequality and the Canadian Charter of Rights And FreEdoms 317 (Sheila McIntyre \& Sanda Rodgers eds., 2006)).

33 See, e.g., Gavigan \& Chunn, From Mother's Allowance, supra note 2.

34 See Pat Armstrong, The Welfare State as History, in The Welfare State in Canada: Past, Present and Future 52 (Raymond B. Blake, Penny E. Bryden \& J. Frank Strain eds., 1997) (for example, Old Age Pensions Act, R.S.C. 1927, c. 156; Family Allowance Act, 1944, S.C. 1944-45, c. 40; Old Age Security Act, S.C. 1951 , c. 181).

35 Gavigan, Paradise Lost, supra note 11, at 607-08; Gavigan \& Chunn, From Mother's Allowance, supra note 2.

36 Gavigan \& Chunn, From Mother's Allowance, supra note 2.

37 McIntosh, supra note 2. 
seldom calls to mind the idealized notion that one's home is one's castle. Rhetorical commitment to familial privacy is asserted and matched by circumscription. Rather than being relegated to the realm of an inviolable "private," families and the women in them have always straddled the ideological "public/private" divide.$^{38}$ For the poor and the marginalized, the implications have been complex, uneven and contradictory. The poor family, long regarded as a site of social dysfunction and source of social problems, has been both hyper-regulated and surveilled, and ignored and under-supported.

Recently, Canadian feminist socio-legal scholars have begun to analyze neo-liberalism and social conservatism - the Scylla and Charybdis of contemporary Canadian social and economic policy - through interrogations of the premises, practices and implications of the "public/private divide" and "privatization." 39 While the areas of law and policy addressed have been wide - taxation law, ${ }^{40}$ immigration law, ${ }^{41}$ pensions and securities regulation, ${ }^{42}$ child welfare law, ${ }^{43}$ labor law, ${ }^{44}$ health law and policy ${ }^{45}$ - my particular focus in the next section of the Article is on feminist analyses of the discourses and gendered implications of "privatization" in the context of family law and social welfare legislation, respectively. ${ }^{46}$ In particular, I ask whether a

38 Gavigan \& Chunn, From Mother's Allowance, supra note 2, at 737.

39 See, e.g., Susan B. Boyd, Challenging the Public/Private Divide: Feminism, Law and Public Policy (1997); Brenda Cossman \& Judy Fudge, Privatization, Law and the Challenges to Feminism (2002).

40 Lisa Philipps, Tax Law and Social Reproduction: The Gender of Fiscal Policy in an Age of Privatization, in Privatization, Law and the Challenge to Feminism 41 (Brenda Cossman \& Judy Fudge, eds., 2002); Claire F.L. Young, Taxing Times for Lesbians and Gay Men: Equality at What Cost?, 17 DalHousie L.J. 533 (1994).

41 Audrey Macklin, Public Entrance/Private Member, in Privatization, LaW and the Challenge to Feminism, supra note 40, at 218.

42 Mary Condon, Privatizing Pension Risk: Gender, Law, and Financial Markets, in Privatization, Law and the Challenge to Feminism, supra note 40, at 128.

43 Marlee Kline, Blue Meanies in Alberta: Tory Tactics and the Privatization of Child Welfare, in Challenging the Public/Private Divide, supra note 39, at 330.

44 Judy Fudge, From Segregation to Privatization: Equality, the Law, and Women Public Servants, 1908-2001, in Privatization, Law and the Challenge to FEMINISM, supra note 40, at 86.

45 Joan Gilmour, Creeping Privatization in Health Care: Implications for Women As the State Redraws Its Role, in Privatization, Law and the Challenge to FEMINISM, supra note 40 , at 41 .

46 See, e.g., Susan B. Boyd, Child Custody, Law and Women's Work 215-18 (2002); Susan B. Boyd \& Claire F.L. Young, Feminism, Law and Public Policy: Family Feuds and Taxing Times, 42 Osgoode Hall L.J. 545 (2004); Brenda 
"tectonic shift"47 can in fact be demonstrated.

\section{B. Something New for the Family? Privatization/Reprivatization}

The nature and implications of various judicial and legislative victories, notably in relation to the extension of the definition of spouse and relationship recognition more generally, have been subject to critical scrutiny and interrogation at every instance, level, and turn. ${ }^{48}$ The triumph of neoconservative and neo-liberal discourse that now informs the social and economic policies of most governments in the global West and North and the coincidence of the rise and success of same-sex relationship recognition and marriage campaigns figure prominently in the critiques and have led to the assertion of some causal claims.

The discourse of the primacy of the private, or its market, as "the driving force in the economy, ${ }^{\prime 49}$ has shaped and informed the policies of Canadian governments since the election of Brian Mulroney's Conservative government in 1984. Since Mulroney's early, rather conventional pronouncement quoted above, Judy Fudge and Brenda Cossman argue that privatization has come to "signify" - no less than a "tectonic shift in public policy" 50 of the liberal state: "Privatization has come to represent a fundamental shift not only in government policies but also in the balance of public and private power, both globally and nationally. It also exemplifies the coincidence of social conservative and family values rhetoric and the neo-liberal goals of selfreliance in public policy." ${ }^{\text {51 }}$ Eschewing a conceptualization of privatization as either simple or straightforward, Fudge and Cossman argue that the process involves "a reconfiguration of the form of state regulation, rather than [simply] deregulation"s2 and a "fundamental retrenchment of the state

Cossman, Family Feuds: Neo-Liberal and Neo-Conservative Visions of the Reprivatization Project, in Privatization, Law and the Challenge to Feminism, supra note 40 , at 169.

47 Judy Fudge \& Brenda Cossman, Introduction: Privatization, Law and the Challenge to Feminism, in Privatization, Law and the Challenge to Feminism, supra note 40 , at 3 .

48 See, e.g., Boyd \& Young, supra note 46; Cossman, supra note 46; Gavigan, Paradise Lost, supra note 11; Gavigan, supra note 32.

49 Fudge \& Cossman, supra note 47, at 3 (quoting former Canadian Prime Minister Brian Mulroney).

50 Id. at 3-4.

51 Id. at 4.

52 Id. at 19. 
in social reproduction, leaving families and charities to shoulder a greater part of the burden for people." 53

Their more complex view of privatization suggests a constellation of strategies: reregulation, reprivatization, individualization, commodification, familialization, delegation, and depoliticization. ${ }^{54}$ Fudge and Cossman speak of "once public goods and services" which are being "reconstituted as private" (in the case of reprivatization), "reconstituted as naturally located within the realm of the family" (as in the case of familialization), or "reconstituted as market goods and services" (in the case of commodification). ${ }^{55}$ However, in the context of family and welfare law, this notion of "once public goods and services" does raise the question of precisely when the golden age of "once" was - a question that, as Dorothy Chunn and I have argued elsewhere, really needs to be answered and demonstrated historically rather than asserted rhetorically. ${ }^{56}$

Does this conceptualization of "reprivatization" and of "familialization" as a central strategy of privatization in the current context capture an actual shift in both official discourse and policy? Does it actually capture the discursive and policy shift in social assistance law? ${ }^{57}$ While the "de-famililializing" nature of the neo-liberal privatization agenda is acknowledged, ${ }^{58}$ familialization appears to be of more consequence. In order to bring "reprivatization" and a (reconstituted) familialization into their theory of privatization, Fudge and Cossman are required to incorporate a neo-conservative commitment to the traditions and values of the patriarchal family into the privatizing strategy. But, the result of adding the fabric of neo-conservative family values to privatization, or even "reprivatization," is not illustrative of the complexity of the process. They are akin to hand-me-down clothes, often a poor fit.

In my view, demonstrative evidence of a "tectonic shift" in state policy with respect to the family requires an analysis of the nature of the shift in neoliberal state policy - away from support for the family - in which a form of "defamilialization" can be seen as one of the key strategies of neo-liberal privatization and its legislative instruments. ${ }^{59}$ Within feminist discourses of privatization, the welfare state has been restructured along leaner and

53 Id. at 18.

$54 I d$. at 20-21.

$55 \mathrm{Id}$.

56 See Gavigan \& Chunn, From Mother's Allowance, supra note 2.

57 Cossman, supra note 46.

58 Id. at 211.

59 See Janet Mosher, Intimate Intrusions: Welfare Regulation and Women's Personal Lives, in THE Legal Tender of Gender, supra note 2, at 165, 167. 
meaner lines, and the focus of welfare policy has shifted such that the state is "reinforcing certain private familial responsibilities for women's poverty ... while diminishing public societal commitment to alleviating that poverty." $" 60$

With respect to family law in particular, Canadian feminist family law scholar Susan Boyd has argued that the discourse of privatization is "currently infusing law and social policy in Canada." ${ }^{61}$ For Boyd, three themes of privatization may be found in the area of child custody ${ }^{62}$ : first, the reinforcement within child custody law of women's privatized responsibility for childcare within family units, and in particular, women's unpaid private responsibility for caring labor; second, the invisibility of women's care-giving labor which is privatized within the family; and, finally, the fact that, in the area of women's personal lives, "mothers who deviate from the norm often feel obliged to hide or privatize their non-conforming life choice."63

There are different meanings attached to privatization here. However, to reiterate a question that I have asked elsewhere, how, if at all, do any of these three themes illustrate privatization ${ }^{64}$ The discourse of privatization simply does not allow one to analyze the ideological nature of the "private" family or the "public/private" split, and the very real fact that primary responsibility for family and childcare has always been primarily "private" and gendered. In my view, the discourse of privatization has stronger resonance for women's child-caring in the contexts of healthcare policy (the shifts to homecare, the cuts to hospitals) and education policy (with cuts to early childhood, kindergarten and after school programs, and the erosion of public education through, among other things, tuition tax deductibility for private schools, to cite the most obvious few). In sum, Boyd's analysis of the history and complexities of child custody law and law reform does not require the new discursive mode of privatization, although clearly privatization affects her areas of concern in a host of other care-giving contexts. Surely the discourse of "privatization" sits uneasily in the context of marriage and familial relations more generally, resting as it does on the very real material foundations of gender inequality within patriarchal familial relations.

As I have suggested above, twentieth-century family law reform initiatives introduced tentative, if uneven, inhibitions of the explicitly patriarchal premises

60 Cossman, supra note 46, at 173 (citing Susan B. Boyd, (Re)Placing the State: Family, Law, and Oppression, 9 CAN. J.L. \& Soc'Y 39 (1994)).

61 Boyd, supra note 46, at 215.

62 Id. at 318-19.

$63 I d$. at 219 (emphasis added).

64 Shelley A.M. Gavigan, Book Review, 20 CAN. J. FAM. L. 229, 237 (2003) (reviewing Boyd, supra note 46). 
of nineteenth and early twentieth-century family law. ${ }^{65}$ The inevitability and desirability of marriage and family may be celebrated socially and culturally, but family law reform has also been informed, at least implicitly, by the understanding that marriage and cohabitation involve economic disadvantage, the visibility of which most often only becomes apparent or acknowledged at the end of relationships. ${ }^{66}$ While it is now almost axiomatic to invoke a domino-like causal relationship flowing from separation and divorce to the feminization of poverty, a more compelling argument points to the feminization of poverty within marriage and the family - derived from and reinforced by the gendered nature of property ownership, labor, and wealth accumulation, and replicated and reproduced by the gendered division of domestic and childcare labor within the home.

To its credit, Canadian family law legislation invokes the language of disadvantage, burden and hardship in relation to familial relationships, not simply at the point and in the aftermath of their breakdown. Canada's federal Divorce Act identifies the objectives of a spousal support order as recognition of the economic advantage or disadvantage of the spouses arising from marriage or its breakdown, the apportioning of financial consequences arising from caring for children of the marriage, relieving the economic hardship arising from marriage breakdown, and the promotion of self-sufficiency within a reasonable period of time. ${ }^{67}$ The Ontario Family Law Act's itemization of the purposes of spousal support orders similarly includes the sharing of the economic burden of child support, relief of financial hardship, and recognition of each spouse's contribution to the relationship and the economic consequences of the relationship. ${ }^{68}$

In the next Part I demonstrate both the ongoing analytic relevance and material expressions of patriarchal ideology, even in contexts where, at first glance, there may be no obvious patriarch (as the litigants AA and CC might claim of their situation) - as in the case of lone parent welfare mothers, or where there is a clear patriarch — as in the case of polygamy. I also critically interrogate the application of the discourse of privatization in family law, in particular in relation to the legal victories regarding the "spouse in the house"

65 See, e.g., Boyd, supra note 46; Carol Smart, The Ties That Bind: Law, Marriage and the Reproduction of Patriarchal Relations (1984).

66 SMART, supra note 65.

67 Divorce Act, R.S.C. 1985, c. 3, s. 15 (Can.). In section 15.2(4), the act itemizes factors to be considered in the making of a support order, including the functions performed by each spouse during cohabitation and any agreement or arrangement relating to support.

68 Family Law Act, R.S.O. 1990, c. F-3, s. 33(8) (Can.). 
in welfare law and same-sex relationship recognition; in particular, I take issue with the characterization of "privatized lesbians" in family law. Through the exemplars of lesbian spouses, polygamous wives, and lone parent mothers on welfare, I demonstrate both the limits of a narrow focus on privatization, especially one that does not simultaneously attend to the patriarchal content of the privatized forms and sites, and the continuing importance of a critical engagement with patriarchal ideology itself.

\section{Women at the Outskirts of Family LaW}

\section{A. The "Privatized" Lesbians of Family Law}

In the landmark Canadian case, $M . v$. $H$., the lesbian applicant argued that the opposite sex requirement of the definition of spouse for the purposes of spousal support (but not family property) violated her equality rights under the Canadian Charter of Rights. ${ }^{69}$ Her claim was resisted by both her former partner as well as the government, which sought to protect its legislation from Charter challenge and any expansion of its coverage. Cossman argues that the result in this case has contributed to the construction of "privatized lesbians." "70 Even though she acknowledges that the case was not argued in these terms or on this issue, and there was no suggestion that the applicant $M$. had required or sought social assistance after the separation, Cossman argues that the antidiscrimination sex equality argument converged with "neoliberal discourses of formal equality and privatization" because the court in one paragraph "placed considerable emphasis on the goal of 'reducing the strain on the public purse' by 'shifting the financial burden away from the government and on to those partners with the capacity to provide support for dependent spouses." "71 Thus, $M$. v. H. emerges as a victory for "neoliberalism in the judicial form." 72 But it can be argued with equal force that M. was arguing for the expansion of her public rights, in the form of family law legislation. Surely a real instance of "neo-liberalism in the judicial form" would have rejected M.'s claim, leaving her in the (private) realm of contract law, making and proving a private agreement with her domestic partner. $^{73}$

69 M. v. H., [1999] 2 S.C.R. 3 (Can.).

70 Cossman, supra note 46.

71 Id. at 189 (emphasis added).

72 Id. at 190.

73 Mary Becker, Problems with the Privatization of Heterosexuality, 73 DENv. U. L. REv. 1169 (1995-1996); Martha Ertman, Contractual Purgatory for Sexual 
The discourse of privatization has been applied within family law by feminists who are both wary and critical of the "victories" achieved by and on behalf of women seeking to obtain spousal and child support from men. Anything that involves the enforcement of a patriarchal familial relation now is characterized as an instance of privatization by family law. If individual men are required to pay child support for children to whom they stand in loco parentis, or to their former spouses, this is characterized as an instance of privatization. Why privatization, not familialization, one wonders? Has privatization become a readily invoked "unexamined vocabulary co-existing with other vocabularies?" 74 If this is an instance of privatization, what vocabulary or discourse can be invoked to capture the alternative result: the "privatization" of financial resources and wealth in the hands of men within and at the end of marriage? The fact that family law legislation structures and frames the legal obligations, responsibilities and expectations of family members, including a right to financial support, is taken to mean that efforts to enforce - or extend - those rights and obligations are part of a ploy to avoid demands being made on the state. It is important to remember here that the primary responsibility for economic support of family members has always rested with the family, in particular, with the male breadwinner.

Interestingly, in this discourse, privatization is deployed primarily in the context of support and child custody - not family property, arguably the primary site of private (male) wealth in families. More recently, this critique has been extended to "non-patriarchal" relations. With the success of various campaigns and Charter-based litigation for the recognition of samesex relationships, some feminist and queer legal theorists have argued that the very campaign for the extension of the definition of spouse and equal marriage reflects a "privatizing" strategy or, perhaps more aptly, a strategy that serves the interests of privatization. The concept of the "private" - and most certainly "patriarchal" — has been displaced by the mantra of privatization. Finally, one surely has to ask where the "once public goods and services" are in the history of same-sex relationships. Surely, no group has been more privatized historically than lesbians - not even subjected to the kind of public denunciation associated with gay men through criminalization of their sexual expression and activity.

Marginorities: Not Heaven, but Not Hell Either, 73 Denv. U. L. Rev. 1107 (1995-1996).

74 Jock Young, From Left Idealism to the Rule of Law, in CAPITALISM AND THE Rule OF LAW 12 (Bob Fine ed., 1979) (attributing the quoted phrase to E.P. Thompson in another context). 
While there is no patriarch in these cases of ostensibly privatized lesbians, the discourse of privatization has been extended from contexts in which it is used instead of "private" and "patriarchal." In neither instance, does the application of the discourse of privatization in familial contexts - same-sex or heterosexual - permit an analysis of the actual social relations and social policies involved. And, as I have demonstrated above, one need not have a patriarch in one's home to have a patriarch in one's head.

\section{B. Patriarchy's Non-Nuclear Outskirts: Polygamous Families}

"Family law and policy in Canada are now characterized by a flexible pluralism that reflects the acceptance of multiple traditions and changing family forms." 75

Calls for the repeal of the offense of polygamy, long housed and seldom prosecuted as a criminal offense in Canada,${ }^{76}$ have been ignored by the Federal Parliament. ${ }^{77}$ Polygamy's retention in the Criminal Code has again come under scrutiny and its outcast legal status has been the subject of recent debate in Canada, sparked in part by rethinking of the merits of its continued criminalization by some feminists, ${ }^{78}$ who have taken a fresh look both at the criminal law and polygamy's supposed "mischief," of its harms for women and children. Recently, polygamy has entered into mainstream popular culture in North America, thanks to HBO's television series, Big Love ${ }^{80}$ and the possibly more accessible reality television series, Sister Wives. ${ }^{81}$

In scholarship, as well, differing accounts of the lives and experiences of women and children in polygamous relationships are appearing in forms

75 IV Vanier Inst. of the Fam., Families Count: Profiling Canada's Families, at xix (2010).

76 See, e.g., Law Reform Commission of Canada, Working Paper 42: Bigamy (1985).

77 See Nicholas Bala et al., An International Review of Polygamy: Legal and POLICY IMPlications FOR CANADA 28 (2005) (a report prepared for Status of Women Canada); see also Jaime M. Gher, Polygamy and Same Sex Marriage - Allies or Adversaries Within the Same Sex Marriage Movement, 14 WM. \& Mary J. Women \& L. 559, 589 (2008).

78 See, e.g., Bailey, Baines, Amani \& Kaufman, supra note 7; Drummond, supra note 6.

79 Drummond, supra note 6.

80 Big Love (HBO 2006).

81 Sister Wives (TLC 2010). 
beyond the television screen. Angela Campbell, a Canadian legal academic, has undertaken empirical research with women followers in the Fundamentalist Church of Jesus Christ of the Latter Day Saints, located in the community of Bountiful, British Columbia. ${ }^{82}$ The community has been in the news over the last few years, following the British Columbia government's unsuccessful attempt to prosecute two avowed, self-proclaimed polygamist men. ${ }^{83}$ The government referred the question whether the criminal offense violates Canada's religious freedom guarantees to a judge of the British Columbia superior court, and this matter is currently being argued. ${ }^{84}$

Some of the women of the Bountiful community agreed to be interviewed by Campbell, motivated in part it seems by a desire to have "their" side of the story of polygamy told. For her part, Campbell also sees her research as part of a larger scholarly project of "accessing and giving credence to women's varied experiences" and providing a balance to media accounts and secondary sources where these women are "often cast as exploited and damaged." 85 She writes:

Women in this community might appear to be subjugated to their husbands and to the male leaders of the community: unlike the men, they are precluded from having plural spouses, and they do not wield public political leadership of the group. But is it possible that a look at this community from within might deliver a different account of its power structures? That is, might we see polygamy as something other than the "nadir of women's status and autonomy" ...? ? $^{86}$

In particular, Campbell asks, "might we find [that] women exercise agency in shaping the way their marriages, their families, and the community look and operate?"87 Campbell maintains that she is not suggesting that women's

82 Angela Campbell, Wives' Tales: Reflecting on Research in Bountiful, 23 CaN. J.L. \& Soc'Y 121 (2008).

83 Petti Fong, Polygamy Charges Tossed Out, The Toronto Star, Sept. 24, 2009, http://www.thestar.com/article/700192.

84 The Canadian Press, Polygamy Law Persecute Bountiful, B.C.: Lawyer, CTV News (Nov. 24, 2010), http://www.ctvbc.ctv.ca/servlet/an/local/CTVNews/20101124/ bc polygamy 101124; see also Olivia Ward, Polygamy: Multiple Choice for Men, No Choice for Women, The Toronto StaR, Nov. 27, 2010, http://www. thestar.com/news/world/article/897904. On November 23, 2011, the British Columbia Supreme Court upheld the constitiotionality of the polygamy offence, Criminal Code, B.C.S.C. 2011, S. 293 (Can.).

85 Campbell, supra note 82, at 123.

$86 I d$. at 126 (footnote omitted).

87 Id. 
perspectives should be accepted without critique; however, in her "counternarrative" of "Bountiful Voices," 88 one arguably encounters but modest expressions of any critique.

Research which provides insight into the voices and reflections on the experiences of "outsiders" is always to be welcomed, especially when those voices are seldom if ever heard in law. It is beyond the scope of this Article to engage with every aspect of Campbell's research at Bountiful; my primary interest is to interrogate the counter-narratives she presents to determine whether the dominant narrative, from which she wishes to distance her research, may be found in them. For instance, some of the women interviewed make it clear that they were part of "placement marriages" and "assigned" to husbands pursuant to arrangements made by their fathers before they reached the age of sixteen:

Well, we had placement marriages. And so when my father told me had said that, that he wanted me to marry a man from Canada, I just said "Why?" I'd never been to Canada. It's so far away and . . I didn't really want to be a plural wife. But I didn't want to disappoint my father, who was everything. . . . I started screaming "I'm not gonna do it!" And I had that choice and he was just so disappointed and that was it. I had that choice. I didn't have to. Then I decided that I didn't want to disappoint him. I really respected him. ${ }^{89}$

"Underage marriage" emerges as a "past custom"; 90 however, some of their daughters nonetheless still appear to experience "peer pressure" to marry in their teens. ${ }^{91}$

Accounts of sexuality, contraception and reproduction were "intriguing." One of the women told Campbell:

I have never had anyone say to me, "You shouldn't use birth control." But it's definitely implied. And it's, I don't think, I mean talking to my own husband, he would never feel like that was appropriate. Because, I guess it's just not the natural thing. It's not what, I guess, we were designed to use or whatever. At the same time though, I think, a lot of women are not really able to communicate their feelings when it

88 Angela Campbell, Bountiful Voices, 47 Osgoode HaLl L.J. 183 (2009).

89 Id. at 195 (Participant \#10).

90 Id. at 200.

91 Id. at 201.

92 Id. at 204. 
comes to [saying]: "Okay, I've had ten children, and I probably have what I can take care of." $" 93$

Campbell's informants referred to sexual relations with their husbands as "mating": "When for example, a wife may feel that her husband would like to mate with her she says, "No, Sweetheart, I'm sorry . . .."94 This informant elaborated: "I said [to my husband], 'You'll have to cope with it, because I can't, I can't mate with you right now.' You know? Even though I was nursing, ... I just, I [couldn't] take the risk." 95

Another counter-narrative emerges in the discussion of the plural wives' access to education and employment. Here, the apparent lack of financial support provided by the polygamous husbands gets recast as financial independence of the women. Campbell observes that "the administration of family finances was a particular area where participants indicated their assertion of control and independence" "I6. "I make my own money and pay my own bills. I don't really give him any, [and] I don't take much money, because that way I'm not dependent."97

Another woman described the approach in her plural marriage:

We [the wives] will sit together with him and figure out which bills have to be paid, and who can help out at that time. We do a big camping trip every summer as a family. Each mother donates towards that. But it's easier if each mother worries about her own children's needs. I mean, it's too big for the whole family to worry about every child. ... But then for the big things like bills, like the power bill, then we get together and worry that through. ${ }^{98}$

It is also the case that the women in Bountiful celebrate the companionship enjoyed by the sister-wives and all their children. And, while it would be a very poor feminist who would deny the importance of respecting these and other first-person accounts, one surely has to inquire about the extent to which these accounts are consonant with either contemporary principles and values of family law in Canada - in which marriage is seen as a partnership premised on equality of the spouses - or to the aspersed "dominant narrative" sought to be countered. On their own terms, and in their own words, worrisome

93 Id. at 204 (Participant \#9).

94 Id.

95 Id. at 205.

96 Id. at 213.

97 Id. at 207 (Participant \#17).

$98 I d$. at 213 (Participant \#16). 
forms of substantive inequality and patriarchal privilege (and irresponsibility) are found.

Thus, while some feminists in Canada argue that the polygamous family form is not necessarily the site of subordination of women, and that some forms of "sisterhood" and agency can be found, this all occurs within the context of a particular expression of patriarchal relations. But, in Bountiful, it is not clear what material support, if any, the patriarchs provide for their children; it is not even clear that they pay for the electricity they consume.

\section{Poor Lone Parent Mothers: Life and Law in the "Non-Conjugal" Outskirts of Family Law}

In the 2006 Canadian census, lone parent families were reported to account for $1,414,100$ families in Canada, or just under sixteen percent; the majority $(80.1 \%)$ of these were comprised of women and their children. ${ }^{99}$ The high poverty rates for lone parent mothers in Canada are a matter of public record, ${ }^{100}$ and a great many of these families rely on forms of social assistance for their survival. Less known and appreciated is the fact that almost half of these mothers and their children derive their incomes from the mother's earnings, not social assistance. ${ }^{101}$

One of the most challenging issues for poor mothers is the vexing relationship between family law and welfare law. For poor women conjugality and cohabitation takes on a whole new meaning and significance, which arguably lie at the heart of family law and welfare law in many contexts. ${ }^{102}$ One of the longstanding indicia of a conjugal relationship is cohabitation; indeed, Canadian case law has long held that a conjugal relationship can be ended by "living separate and apart" - which within family law can be found to occur even when spouses are living in the same home. ${ }^{103}$ In other words, it is possible within family law and, importantly, for divorce law that spouses be found to be living separated and apart, and hence not in a conjugal

99 Statistics Canada, Family Portrait: Continuity and Change in Canadian FAMILIES AND HOUSEHOLDS IN 2006, at 15 (2007).

100 See, e.g., National Council of Welfare, Welfare Incomes 2002 (2003).

$101 \mathrm{Id}$.

102 See, e.g., Shiri Regev, Revealing Realities Beyond the Formal Law: Untold Stories of Israeli Single Mothers Living on Welfare (May 2006) (unpublished LLM. thesis, Stanford University), available at https://www.law.stanford.edu/ publications/dissertations_theses/diss/RegevShiri-tft2006.pdf (analyzing Israeli welfare law). I am grateful to the author for permission to cite her work.

103 In Ontario, the leading case is Moldowich v. Pettinen (1980), 17 R.F.L. 2 d. 376 (Can. Ont. D.C.). 
relationship, while still living under the same roof. But, as women on welfare know, the poor family can be dissolved for the purposes of family law whilst being regarded as intact for the purpose of social assistance.

One of the longest standing and most controversial issues in Canadian welfare law is the history of the "spouse in the house" legislation. ${ }^{104}$ Surely, no aspect of welfare law has been subjected to more intense critical feminist scrutiny and analysis than has the spouse in the house - and the commitment to patriarchal premises of family and child support it represented. ${ }^{105}$ In 1986 , Canadian feminist legal advocates believed they had made history, and indeed they had. One of the first areas of law challenged for violating the equality guarantees of the Charter of Rights and Freedoms was the "spouse in the house" regulation in Ontario's Family Benefits Act ${ }^{106}$ In an historic settlement, the provincial government agreed, for the first time ever, that the definition of spouse in welfare law should track the definition of spouse in family law. For women on welfare, this meant that if they began to cohabit with a man who was not the father of their children, he would not be deemed to be a spouse until the period of their cohabitation met the three year period provided under the Family Law Act. ${ }^{107}$ In other words, during the period when he did not have a legally enforceable obligation to provide financial support to her, or to her children, he could not be brought in as a spouse in the social assistance context. Additionally, and in the spirit of respecting and protecting the privacy of women on welfare, the regulations also provided that sexual factors could not be relied upon in determining whether the man was a welfare mother's

104 As Regev, supra note 102, has demonstrated, it may also be "spouses in the house" in the context of polygamous families, such as the Bedouin in Israel.

105 See, e.g., Margaret Little, No Car, No Radio, No Liquor Permit: The Moral Regulation of Single Mothers in Ontario, 1920-1997 (1998); Janet Mosher, Patricia Evans, Jo-Anne Boulding \& Nancy VanderPlaats, Walking on EgGShells: Abused Women's EXPeriences of Ontario's Welfare System (2004), available at http://osgoode.yorku.ca/osgmedia.nsf/0/2930D464471B479F852 5709A0053CEB6/\$FILE/walking\%20on\%20eggshells\%20final\%20report.pdf; James Struthers, The Limits of Affluence: Welfare in Ontario, 1920-1970, at 1 (1994); Margaret Little, A Litmus Test for Democracy: The Impact of Ontario Welfare Changes on Single Mothers, 66 Stud. PoL. Econ. 9 (2001); Melodie Mayson, Ontario Works and Single Mothers: Redefining 'Deservedness and the Social Contract,' 34 J. CAN. STud. 89 (1999); Veronica Strong-Boag, Wages for Housework: Mothers 'Allowances and the Beginnings of Social Security in Canada, 14 J. CAN. Stud. 24 (1979).

106 Family Benefits Act Regulations, R.R.O. 1980, Reg. 318, s. 1(1)(d)(iv), amended by O. Reg. 589/87, s. (1) (Can.).

107 Family Law Act, S.O. 1986; see also LiTTLE, supra note 105, at 153-56. 
spouse. In other words, the fact that a woman might be sexually involved with a man was not to be considered. However, and paradoxically, neither could the absence of a sexual relationship be relied upon to deny the existence of a spousal relationship.

In 1995, as Dorothy Chunn and I have discussed elsewhere, Ontario's welfare laws were dramatically restructured and reshaped by the newly elected Conservative government. ${ }^{108}$ The very first acts of the Conservative government included a twenty-two percent across the board cut to social assistance benefits, reducing the incomes of welfare recipients to further depths beneath the poverty line. Single mothers on welfare, for instance, saw their incomes drop to fifty-eight percent of the national low income cutoffs, Canada's "poverty line."109 A new, expanded definition of "spouse" was introduced which provided that an individual who lived with a welfare recipient could be found to be a spouse, even though by any other (family law) definition of spouse there would be no recognized familial relationship or support obligation. In the immediate aftermath of the redefinition of spouse, ten thousand welfare mothers (and their dependent children) had their welfare benefits terminated for this reason alone; seventy-eight percent of welfare recipients whose benefits were terminated as a result of the new definition were mothers. ${ }^{110}$

These mothers and their dependent children were left without recourse either to social assistance (as long as they continued to reside with the man who was providing no financial assistance to the household) or to legally enforceable support obligations, because the "spouses" who had caused their disentitlement to welfare were not legal spouses for any other purpose. Despite the legally discursive construction of "spouse," the primary purpose and effect of the expanded definition of spouse was to remove these women and children from the welfare rolls - to terminate their benefits - not to relegate them to the care and support of a husband/father.

Following a successful challenge to the new definition of spouse, ${ }^{11}$ which saw it struck down, the government responded by a modest extension of the "grace period" to three months, but in a clear effort to resist importing a family

108 Chunn \& Gavigan, supra note 11; see also Mosher, Evans, Boulding \& VANDERPLAATS, supra note 105.

109 National Council of Welfare, supra note 100, at 28 tbl. 2.1.

110 As discussed below, the Ontario Court of Appeal ultimately struck down this provision as a violation of the welfare mothers' equality rights under the Canadian Charter of Rights and Freedoms, see Falkiner v. Ontario, [2002] 59 O.R. 3d 481 (Can. Ont. C.A.).

111 Id. 
law interpretation of "cohabitation" or "living separate and apart" in the same home, the government widened the definition and closed the door to family law jurisprudence. The definition of spouse no longer requires cohabitation, but simply co-residence in the same dwelling house:

"[S]pouse", in relation to an applicant or recipient, means, ...

(c) a person who has an obligation to support the applicant or recipient or any of his or her dependants under section 30 or 31 of the Family Law Act, whether or not there is a domestic contract or other agreement between the person and the applicant or recipient whereby they purport to waive or release such obligation to support, or

(d) a person who has been residing in the same dwelling place as the applicant or recipient for a period of at least three months, if,

(i) the extent of the social and familial aspects of the relationship between the two persons is consistent with cohabitation, and

(ii) the extent of the financial support provided by one person to the other or the degree of financial interdependence between the two persons is consistent with cohabitation.

(2) For the purpose of the definition of "spouse," sexual factors shall not be investigated or considered in determining whether or not a person is a spouse. ${ }^{112}$

Assessing the import of the broad definition of spouse in welfare law, with resultant restrictions on access to benefits, Cossman has argued that "[f]amily law is displacing social welfare as the primary financial source for persons without market incomes." 113 This assertion requires close critical interrogation in two important respects. It implies that social assistance ever provided adequate financial support for families without access to market incomes, and that social assistance actually provided an alternative to familybased support. ${ }^{114}$ The historical record of the legislation does not support this

112 O. Reg. 134/98 under Ontario Works Act, S.O. 1997, c. 25 (Can.).

113 Cossman, supra note 46, at 173 (emphasis added).

114 In the province of Ontario, the Ontario Works (OW) rate for a single mother with one child is approximately $\$ 800$ per month; in addition, this mother is eligible to receive the Child Tax Credit (CTC) under the program that replaced the Family Allowance Plan. The stated objective of the CTC, as a "targeted" program, is to assist low income families with children. However, the CTC (approximately $\$ 150$ per child) is regarded as income by $O W$ and is deducted from the benefits. 
claim; ${ }^{115}$ and there is simply no empirical evidence that in the current context family law is doing what is claimed here. The enforcement of a child or spousal support obligation seldom replaces social assistance. Usually, it supports the government but not the mother, because if she is on assistance, her monthly benefits are deducted by the amount of support received. Neither form of financial support ever really meets the needs of a woman and her children.

The Keynesian approach to social policy and the family neither attempted nor sought to dislodge, or render public, the most significant source of women's poverty and inequality in the labor force: their primary responsibility for the care and wellbeing of their children. Despite the tentative expansion of the welfare state in Canada, and the Canadian women's movement's tireless efforts to place universal access to excellent childcare at the center of Canadian public policy, responsibility for this most ideologically enduring aspect of women's work (together with cleaning toilets) never shifted from women to men, from mothers to fathers, from wives to husbands, from the "private" to the "public." This "private familial" good and service never went public in order to be "reprivatized" or "re-familialized" in the era of neo-liberalism and privatization. The same can surely be said with respect to spousal and child support, domestic labor within the home, responsibility for elder care, and so on. Primary responsibility for "private" family relations has never not been located within the family - discursively or otherwise. ${ }^{116}$

\section{Conclusion}

This Article has explored tensions and contradictions within and between feminist socio-legal theorizing of ("private") family law and ("public") welfare law as illuminated by the feminist engagement with privatization, same-sex relationships, and polygamy. Throughout, I have attempted to demonstrate the continued importance of attending to and engaging with patriarchal ideology and patriarchal relations, even at the outskirts of family law - where one might or might not find a resident patriarch.

The more apt description of the provincial's government's policy is "claw back." The same is true for any child or spousal support payments that might be received by a single mother. They too are deducted from the monthly $\mathrm{OW}$ benefits. Thus, the poorest mothers in Ontario do not receive the benefit of programs that are designed to alleviate child and family poverty.

115 Gavigan \& Chunn, From Mothers' Allowance, supra note 2.

116 Id. 
Canada is a country of committed, if often serial, monogamists - samesex or straight. ${ }^{117}$ Polyamorous relationships in Canada are statistically insignificant. ${ }^{118}$ So too are polygamous relationships, if ideologically more potent; they clearly have captured the imagination of Canadian researchers and crown prosecutors. The same might be said for same-sex couples. Enumerated for the first time in 2006, the 2006 Census reported that same-sex couples represented $0.6 \%$ of all couples in Canada that year. ${ }^{119}$ And, for all the vaunted achievement of same-sex marriage in Canada, only 7,465 (sixteen percent) of 45,345 same-sex couples counted in the 2006 census reported that they were legally married. ${ }^{120}$ It is important to be attentive to the larger context in which all these relationships exist.

Finally, for all the concerns about privatization - and there are many - it is important to be attentive to the contradictory possibilities that nonetheless may be offered by contract in family law. Reliance on contract, notably "contracting out" of family law regimes, has become a prominent feature of the Canadian family law landscape. While there are differing assessments of the adverse implications for women of the ascendancy of contractual forms (marriage contracts, separation agreements), the preponderance of feminist family law scholars have raised serious concerns about the implications of judicial blessings bestowed on husbands who seek to avoid/evade statutory provisions premised on sharing and equity. ${ }^{121}$

117 Statistics Canada, supra note 99, at 8 tbl. 1. The 2006 census "snapshot" of Canadian families indicates that of $8,896,840$ families in Canada, $84.1 \%$ $(7,482,775)$ were "couple families" (either legally married $(68.6 \%)$ or common law $(15.5 \%)$ ); the remaining $15.9 \%$ were comprised of female $(12.7 \%)$ or male $(3.2 \%)$ lone parent families.

118 There is very little research into these forms of relationships in Canada. For a study of polyamorists in the Bay Area of San Francisco, California, see Hadar Aviram, Make Love, Not Law: Perceptions of the Marriage Equality Struggle Among Polyamorous Activists, 7 J. BISEXUALITY 261, 269 (2008) (finding that the polyamorous activists she interviewed were not particularly interested in securing the right to marry; rather, they tended to eschew state or legal regulation, although it must be noted that some acknowledged other forms of legal regulations, and not so unconventional explanations for resisting marriage. In the words of one of Aviram's female informants, "If I got married I'd lose my benefits as a single mom." Another, a man named Roger, "a retired professional in his seventies," has a number of girlfriends to whom he is "committed" but "manages his finances by himself and prefers it that way.").

119 Statistics CanAda, supra note 99, at 12.

120 Id.; see also VANIER INST. OF THE FAM., supra note 75, at 40-41.

121 See, e.g., Boyd \& Young, supra note 46; Brenda Cossman, A Matter of Difference: 
However, provincial family law legislation does require, with slightly varying tests, judicial oversight of domestic contracts, in order to ensure that spouses who fail to disclose assets or who take advantage of the other spouse's vulnerability are not able to rely upon them. Similarly, domestic contracts cannot limit judicial oversight with respect to child support and the best interests of dependent children, and finally, provisions of domestic contracts which purport to impose chastity requirements will not be enforceable. ${ }^{122}$

There are many different legal familial contexts in which patriarchal claims continue to be advanced within the context of rights claims. In what can only be characterized as a distressing case from 2003, the Supreme Court of Canada retreated to a breathtakingly formalistic interpretation of equality in allowing the claim of a man who maintained his equality rights were violated by legislation which permitted a mother to give the children born of their short-term relationship her name only. ${ }^{123}$ The male claimant was not the spouse of the mother and did not have an active relationship with the children, and indeed made little financial contribution to the children's care and upbringing. Yet, for Justice Marie Deschamps, "a father's ability to include his particulars on a child's birth registration and to contribute to the process of determining the child's surname can reasonably be perceived to be modes of meaningful participation in a child's life."'124

More recently, however, Canada's Supreme Court stared down another patriarchal claim cloaked in religious freedom when it enforced a civil contract between a Jewish couple which had a religious aspect. The contract in question was a "Consent to Corollary Relief," an agreement entered into by the husband and wife in order to settle their matrimonial dispute at the time of their civil divorce. One of the commitments they had made to each other in the agreement was to appear before a rabbinical court to obtain a get. The husband then refused to do so, and maintained his intransigence for fifteen years, relegating his ex-wife to the wilderness. The marriage had been

Domestic Contracts and Gender Equality, 28 Osgoode Hall L.J. 303 (1990); Carol Rogerson, Commentary, They Are Agreements Nonetheless, 20 CAN. J. FAM. L. 197 (2003); Martha Shaffer, Domestic Contracts, Part II: The Supreme Court of Canada's Decision in Hartshorne v. Hartshorne, 20 CAN. J. FAM. L. 261 (2004). Cf. Robert Leckey, Contracting Claims and Family Feuds, 57 U. ToRonTo. L.J. 1 (2007).

122 Family Law Act, R.S.O. 1990, c. F-3, pt. IV (Can.).

123 Trociuk v. British Columbia (Att'y Gen.), [2003] 1 S.C.R. 835 (Can.); see also Gavigan, supra note 32; Hester Lessard, Mothers, Fathers, and Naming: Reflections on the Law Equality Framework and Trociuk v. British Columbia (Attorney General), 16 CAN. J. WOMEN \& L. 165 (2001).

124 Trociuk, [2003] 1 S.C.R. 835 ๆ 16. 
a second one for the husband, and his first marriage had ended by a get. At the time of his second marriage, he had been thirty-seven years of age, and his new wife was twenty. They separated after eleven years of marriage, and by the time the husband finally appeared before the rabbinical court fifteen years later, his ex-wife was forty-seven years of age. She had not remarried nor had any other children. ${ }^{125}$ The husband, relying on his freedom of religion under the Quebec Charter of Rights, ${ }^{126}$ denied the validity of the agreement and further claimed that its religious aspect rendered it unenforceable in a civil court. ${ }^{127}$ The majority of the Supreme Court of Canada disagreed; speaking for the majority, Madam Justice Rosalie Abella characterized the issues and offered a methodology for analysis thereof:

Canada rightly prides itself on its evolutionary tolerance for diversity and pluralism. This journey has included a growing appreciation for multiculturalism, including the recognition that ethnic, religious or cultural differences will be acknowledged and respected. Endorsed in legal instruments ranging from the statutory protections found in human rights codes to their constitutional enshrinement in the Canadian Charter of Rights and Freedoms, the right to integrate into Canada's mainstream based on and notwithstanding these differences has become a defining part of our national character.

The right to have differences protected, however, does not mean that those differences are always hegemonic. Not all differences are compatible with Canada's fundamental values and, accordingly, not all barriers are arbitrary. Determining when the assertion of a right based on difference must yield to a more pressing public interest is a complex, nuanced, fact-specific exercise that defies bright-line application. It is, at the same time, a delicate necessity for protecting the evolutionary integrity of both multi-culturalism and public confidence in its importance. ${ }^{128}$

Justice Abella perhaps has framed the issue for future disputes where, in the context of Canada's vibrant multicultural landscape, some Charter rights and values, such as religious freedom, perhaps especially when cloaking patriarchy, run up against other fundamental Charter values and rights, such as equality.

125 Bruker v. Marcovitz, [2007] 3 S.C.R. 607 (Can.).

126 R.S.Q. c. C 12.

127 Bruker, [2007] 3 S.C.R. 607.

128 Id. at 1 甲ा $1-2$. 
